\title{
Policy, learning and regime change: Western concepts and CEE experience
}

\begin{abstract}
This article offers an outsider's perspective on the place of policy in the analysis of governing in Central and Eastern Europe, both before the change from a communist to a post-communist order, and since. It explores the way in which 'policy' is used as a construct in both the practice of governing and the analysis of that practice. It argues that we have to recognise multiple strands-authority, structured interaction, and collective problematisation - in the construction of 'policy'. It points to a distinction between 'formal' and 'practical' perspectives, and argues that this distinction reflects structural tensions in the process of 'putting together' the shared understandings and relationships which make g for 'governing', It argues for the importance of continuing research, empirically based and theoretically informed, into the way that governing is 'put together' in Central and Eastern Europe, and how both participants and the governed 'make sense' of this process.
\end{abstract}

KEYWORDS: practice of governing; policy; policy analysis; concepts in practice; sense-making

RECEIVED 24 May 2017; ACCEPTED 29 September 2017.

The much-anticipated passage from capitalism to socialism had been theorised ad nauseam in academies, universities and coffee bars from Belgrade to Berkeley, but no-one had thought to offer a blueprint for the transition from socialism to capitalism (Judt, 2006, p. 685).

\section{INTRODUCTION}

The emergence of the Central European Journal of Public Policy reflected a perceived need for a venue for discussion of the distinctive nature of governing in the post-Communist states of central Europe. Ten years on, the editors chose to invite this contribution from an outsider - a 'Westerner' (though Australia is clearly south-east of CEE), and not a 'regional' specialist, but one whose focus is on the analysis of governing and the place of 'policy' within it. This article offers an outsider's perspective on the problematics of governing, which arose in the Central and Eastern Europe over these years, and to which this journal has addressed itself. It does not attempt to be a survey of what has happened in this region, either in the current regimes or previously, but flags some of the questions that (analytically) need to be addressed, and suggests some points that emerge from an outsider's scan of the Central and Eastern European experience. It was felt, both by the editors and the author, that this could be a valuable spur to the continuing discussion in the journal.

The collapse of the Communist regimes across Central and Eastern Europe was a dramatic challenge to both the practitioners in the governmental process and to the observers of it. How could they make sense of the process of governing, how were people to relate to it, and how could it be talked about? Paraphrasing Judt's observation (above), there was no blueprint for the transition from a Communist to a post-Communist political order. Governing is performed by not only the governors, but also by the governed, and reflects shared understandings about 'the order of things'. How did the collapse of the Communist order change the way in which participants in the governing of CEE 'put together' the new mode of governing? And how has the concept of 'policy' been mobilised in the practice of governing, and in the analysis of that practice?

1 H.K. Colebatch: a Visiting Professorial Fellow in the School of Social Science, University of New South Wales. Email: h.colebatch@unsw.edu.au 
The approach that is being followed focuses not primarily on policy, but also on governing, and on governing, which is a process; and not government, which may be seen as an outcome of this process, but is more commonly seen as an institutional formation ('the government'), regarded as an actor that produces the outcome. In this, we follow the lead of the organisational scholar Karl Weick (Weick, 1979), who points to the utility of focusing on the activity ('organising'), which produces the phenomenon ('organisation'), rather than attributing it to the activity of an intentional actor ('the organisation'), which is seen as controlling the actions of the participants so as to attain the desired outcomes for the collectivity.

In this perspective, 'policy' is seen as a particular discourse mobilised in both the accomplishment and the explanation of governing. In the liberal democratic states of the west, it is used to present action as being validated by manifesting the aspects of authority (the action was taken by an authoritative person of his/her subordinates), order (the action is not random or idiosyncratic, but is the normal response), and problematisation (the action is in response to a known problem, which has been addressed in an appropriate way). These elements are variable, and the policy is likely to draw on these elements in different combinations at different points of time and contexts - which is why, the policy is frequently described as 'complex' and 'difficult to define'.

The analytic approach being taken might be described as 'interpretive' or 'social construction', but it is not adopted as a fashion choice; rather, experience shows that it is better at making sense of patterns of governing - particularly where these are changing than more systematic approaches, anxious to fit each empirical example into a categoric box. It is more alert to the ways in which local actors frame their own responses to problematic situations.

This is clearly an outsider's perspective, and an analytical questioning, not an empirical report of practice; it aims to stimulate questioning from researchers working in the region. It does not pretend that Central Europe (let alone Central and Eastern Europe) has a single and unique political experience, but uses the term as a convenient way of focusing attention. Similarly, it does not assume that there was a single, cataclysmic change of governing practice in 1989, any more than (for instance) that the Reformation 'happened' in Germany in 1517 or in England in 1534; there was change before that date and continuity after it, but the date helps to focus attention on the nature and extent of the change.

\section{THE STARTING POINT: THE POST-WAR MAP}

It is best to start with the stories that everyone knows: the 'official account' of government in the CEE countries, and in their counterparts in the West. In the CEE countries, the official accounts pointed to constitutions that provided for elections and legislatures, presidents and prime ministers, courts and police, and a state bureaucracy. In some cases, these also made specific provision for the protection of the rights of individual citizens. But they also usually recognised the 'leading role' of the Communist Party (or its local name) in the governing of the country. Governing, then, was the work of the party, the constitutionally-recognised leaders, and the bureaucracy, carrying out well-publicised 'plans'. It does not appear that 'policy' was a significant concept in the description of analysis of governing; there was no word to identify 'policy' as a distinct aspect of governing in most of the CEE languages, and in the official account, there was less interest in recognising alternatives or innovation. It was a narrative of progress along a known road, led by the party, expressed in the plans and programs of the government, and demonstrated in well-publicised statistics.

While this was an 'official story' that everyone knew, few saw it as a guide to behaviour - either their own, or that of the actors it described. It was clear that legislatures and ministers were of less significance than the party hierarchy, and that the police and courts were more concerned with maintaining political control than enforcing the law (Goetz, 2001; Goetz \& Wollman 2001; Nunberg, 1999, 2000). But there were also silences - known but not talked about. One (with the partial exception of Yugoslavia) was the Soviet system: the political, economic and military dominance of the USSR, whose Red Army had been the army of occupation through which nearly all these regimes were founded, and which had demonstrated that it could, and would, intervene with military force to compel CEE governments to change direction. This also gave rise to a 'horizontal' dimension in CEE, in that the governing in one country could be influenced by events and experiences in others, whether as positive or negative cues.

At the same time, there was what might be thought of as a parallel ordering of practice, at variance with the official story - well described in Janos Kenedi's Do It Yourself (1982). As Kenedi points out, the state-sanctioned collective enterprises struggled to provide the food and services needed, and a significant private sector could be seen, sometimes referred to as the 'second economy', tolerated in various ways, but not officially recognised. In this mode of practice, people found their own ways to discover and obtain what they needed, using contacts, networks, exchange, side payments, and a web of shared understanding. The gap between the official account 
and the realities of practice was also felt in the state system. The rigidities of the system of central planning and quotas meant that in order to ensure that they would be able to meet imposed targets, factory managers would conceal reserves of raw material and labour from higher authority (Judt, 2006, p. 579).

But operating in this shadow world of 'do it yourself' always ran the risk of official discovery and sanctions, which could be very substantial. So people had to learn how to pay deference to the official story, but find ways to 'get by' outside the official system without provoking an official reaction. So, the question 'how does governing happen?' always had to be answered in a specific context: how, in this context, did the participants take note of these three accounts: of official collective activity, of individually negotiated practice, and of the significance of coercion - to guide their practice, and the account they gave of this practice. Being attentive to, and knowledgeable about, all three accounts, became an essential life-skill. And the official, systematic account of governing was recognised as significant but inadequate; you would need more than that to get what you wanted, probably by making side-payments to the officials who found themselves in a position to be gatekeepers.

The official account of governing in the West differentiated a realm of governing ('the state') from a realm of self-interested exchange ('the market'), and a realm of freely-chosen norms and relationships (the 'private sphere'/'civil society'/'the community'). The realm of governing was presented as a necessary complement to the other two, dealing with those matters that could not be managed either by the self-stabilizing working of market exchange, or the moral force of community norms. The official account sometimes refers to the ways in which this separation into market, governing and the private is institutionalised and documented. Since there might be divergent views on what should be governed, and how this should be done, this account posited a chain of authority and responsibility, ultimately resting on some expression of the views of the citizens: the citizens elect a legislature, which in turn appoints the executive, or the electorate may also choose the top executive. These authoritative leaders - the legislature and the executive - make choices about the modes of governing, responding to (or anticipating) the preferences of the citizens; these choices are 'policy', which is implemented by the subordinate officials.

Governing is therefore presented in this account as the execution of choices made by the authoritative (usually elected) leaders, in response to (or anticipation of) the preferences of the public, with policy as the aggregation of these choices. It is not clear to what extent this account was believed, but there were few sanctions for publicly rejecting it. Electoral outcomes were held to demonstrate popular support for the proclaimed programs of the victors ('the electoral mandate'), and the absence of overt censorship was seen as demonstrating a free contest of ideas. Scholarly research challenged some of the key assumptions, for example, that the voters' choices were determined by policy preferences, or drew attention to the participation of non-government actors through 'policy communities' - but these were seen as marginal subtleties rather than major challenges. Those involved in the governing process seemed to be able to manage the discrepancies between the official account of an open competition of ideas and the much more structured and constrained observable practice by accepting that different accounts might 'make sense' in different contexts.

The most substantive overt challenge to the official account came from the market-oriented politicians, arguing (in 'principalagent' terms) that the bureaucracy was likely to be more attentive to its own institutional agendas than to the preferences of political superiors. This gave rise to a rhetoric of organisational change, termed 'the New Public Management', which incorporated competitive contracting agencies (see Pollitt, 2007; Colebatch, 2005), quantitative indicators and payment by results. The term has had a high profile in academic discussion (e.g., Christensen \& Laegreid, 2002, 2007), though its utility was questioned (e.g., Hood \& Peters, 2004), particularly for CEE (e.g., Drechsler, 2009; cf. Pollitt \& Dan, 2011; Dan \& Pollitt, 2015). But the reform impetus seems to have subsided, and the term 'post-NPM' is starting to appear.

So, both in the West and in CEE, official account was broadly accepted in the post-war years. In CEE, as we have seen, people had to incorporate the official account into their 'working knowledge'. In the West, while the accuracy of the official account as a representation of practice or a guide to behaviour might be questioned by both practitioners and academics (perhaps for different reasons), it was not challenged as an account. This was seen as an appropriate way to account for governing in public and official contexts. It identified a rationale for governing, and a sphere in which it was practised. It validated the outcome of governing, and the actions of (and the deference to) the authoritative leaders who presided over it. And it provided a channel for critique and innovation: to achieve change in the way governing was carried out, it would be necessary to persuade the leaders to adopt a different policy, or install new leaders who would do this. There is less evidence of how this Western account was used within CEE, but I suspect that in official circles, it was a target for challenge, and in private, it served more as a comparator, an ideal to contrast with their own experience, and so its empirical accuracy was both less evident, and of less significance. 


\section{THE CHALLENGE OF REGIME CHANGE}

The collapse of the Communist regime in the USSR and CEE took many observers by surprise, and there was much puzzling about its implications for governing. The most dramatic interpretation was that of Francis Fukuyama, who saw it as 'the end of history'.

What we may be witnessing is not just the end of the Cold War, or the passing of a particular period of post-war history, but the end of history as such; that is, the end point of mankind's ideological evolution and the universalization of Western liberal democracy as the final form of human government (Fukuyama, 1989).

There has been much disputation since then about what this prediction meant and how analytically helpful it has been. As an outsider, I have had a partial and hence distorted access to the European experience, but let me offer some perceptions and invite critique.

Perhaps the first observation is that what this uprising was against was more evident than what it was for. To some extent, this reflected a strategic choice by dissidents, anxious to avoid provoking further repression by open advocacy of a different political order, but it also reflected variations in motivation. Antipathy to repressive rule and party dominance, and discontent with the shortages and quality of food, consumer goods and housing were felt everywhere, though perhaps in different proportions. In CEE, there was also an anticolonial spur, a reaction to Russian domination. In some cases, ethnic consciousness was part of the story - positive in the case of East Germany, negative in Czechoslovakia and Yugoslavia. The Yugoslavian case also had overtones of regional resentment, with the more-developed Slovenia and Croatia coming to feel that they would be better-off not having to contribute to the needs of the four less-developed states in the federation (Judt, 2006, 670).

But as Fukuyama demonstrated, there was a tendency for Western observers to see it as a resolution of the long Cold War rivalry with the USSR; this was a rejection of the Soviet model, and an embrace of the Western alternative: liberal democratic capitalism. What it meant in Central and Eastern Europe is another question. There had been little empirical research in these countries on the processes of governing before 1989, and there was not a great deal after 1989 on the working of the old order. For both practitioners and researchers, there were questions about the understandings, practices and skills that had served them well in the old order, and how they could adjust to the changing circumstances. Anyone giving an account of change would have to account for their own part in it.

But while there might have been some reticence in CEE about the nature and extent of the change, there were a number of Western institutions ready to instruct the former socialist states on this transition. The World Bank had been actively promoting an agenda of 'good governance' among its client states in the third world, which was focused on creating the institutional basis for a free market, advising governments to remove any constraints on market forces, privatise state functions, reduce public employment, and enforce the rule of law, and it seemed easily applicable to the countries of the 'second world' (to use a designation that had never caught on). This was reinforced by the complementary agenda of the World Trade Organisation, which defined the rules for market competition, had procedures for enforcement, and demanded acceptance of these as a condition of entry to the club.

This reform agenda embodied a zeal for codifying the institutional dynamics of liberal democratic government.

With the collapse [of communism,] the focus of international agencies in the former Soviet Union was on establishing the mechanisms of a capitalist economy through privatization and the creation of free markets. By the mid-1990s, it was clear that markets embedded in corrupt or dysfunctional states would themselves become corrupt and dysfunctional. ... [There was] a renewed appreciation of the importance of governance ... But you cannot fix what you cannot measure, and so underpinning these more visible developments was a quieter but equally important movement to develop indicators of good governance (Buduru \& Pal, 2010, p. 514).

This has involved not only aid agencies and 'official transnational' bodies like the OECD in the codification of good practice, but has also drawn in non-government bodies like the Soros-sponsored Open Society Foundations and Transparency International. So, there have been a number of overlapping and broadly similar templates being applied to the CEE experience by participants from outside (Pottůček et al., 2016). But the most explicit source of modelling has been the European Union, whose acquis communautaire sets out (in 35 chapters) the laws and regulatory principles of the EU, and which provides the basis for the negotiations between the 
CEE candidate states and the EU representatives (and the negotiations may begin before the candidacy) (see Meyer-Sahling, 2009; Madarevic, 2015). But alongside this formal handbook of legal requirements, there is a looser concept of the 'European mode of governance', which refers to the ways of governing 'that are not based on legislation and include private actors in policy formulation' and 'include the open method of coordination, voluntary accords, and regulatory fora' (Heritier, 2004) - a way of governing by negotiation, as compared with the acquis communautaire, which stresses its obligatory and coercive nature. Thus, there has been a very specific reform agenda held out to the countries of Central and Eastern Europe by a range of outside reformers.

\section{MAKING SENSE OF GOVERNING ON CHANGING TERRAIN}

For both participants and observers (and citizens), while the ending of the communist regimes may not have been the end of history, it has added to the uncertainty about how we are governed. There are questions about what are the significant institutions, practices and actors, how they contribute to governing, and in what way 'policy' becomes part of the story. There was not an established culture for the critical examination of governing practices, nor recognisable methodologies and discourses. There had been a recognised way of making sense of governing; that had now been dethroned, but the substitute on offer was not well-known or well-established, and in any case, did not seem to offer much guidance to the mode of governing.

Here, the real problem was the relationship between the model of practice, and the experience of practice, and the questioning of the model by central Europeans was paralleled by a similar questioning in the West of a model that presented governing in terms of authoritative choices by a goal-oriented government. A better-informed public had become more aware that while it was convenient to speak of 'the government', public authority is exercised through an array of organisational forms, linked in various, and not always direct, ways to central political authority. These distinct bodies tend to have specialised and often competing agendas, and are often more closely linked to their functional counterparts outside the government than to the other organisational components of the government. Empirically, the government is more of an arena, where organised voices contend for recognition and resources, than an actor.

Observers also became aware that while the hierarchical authority of government is widely asserted, it is not always clear that this claim is sustained, or that this is the way in which governing is accomplished. For instance, contemporary governments tend to prohibit the use of a range of drugs, but this prohibition seems to have little impact on the use of these drugs, other than to raise the price, and drug use in prisons (where prisoners are under the absolute control of the government) is often as prevalent as it is outside. Even within the official bureaucracy, appeal to hierarchical authority (e.g., to resolve conflicts between agencies) is of limited utility; political leaders are reluctant to expend their time and political capital in struggles with their counterparts, and expect their own bureaucrats to find a mutually-acceptable course of action.

It is evident, too, that there are other forms of authority than the legal-rational authority of the government - most obviously, kinship groups (the family), ethnic and religious formations, occupations and economic groupings — and that actors in the government seek to recruit these into the process of governing (see, e.g., Colebatch, 2002). Governments may endow these groups with official authority, for example, vesting regulatory authority in a professional association or industry body. In some cases, these bodies are called into existence by the government, and may even receive government funding, which makes it difficult to distinguish between 'government' and 'non-government'. It is clear, too, that government actors (particularly political leaders) are very sensitive to the preferences of organised interests, recognise them as 'stakeholders', and seek their prior consent before exercising authority over them - and that failure to do this - described as 'failure to consult' - is sufficient grounds for resisting the exercise of authority. In the liberal democracies, those claiming hierarchical authority learn that it is wise not to place too much reliance upon it (which may point to a very significant difference in the cultural inheritance of the CEE states, not only because of the immediate Communist background, but also because of their long exposure to the European Rechtsstaat tradition).

A second assumption about liberal government, its instrumentality - that governments are there to achieve objectives - had also become less credible. The enunciation of goals has become more important for both political leaders and organisations, both inside and outside the official sphere and the social sciences have developed more specific ways of measuring their achievement. But the public tend to be sceptical of these claims, and empirical research often casts doubt on the extent to which governing can be seen as the pursuit of specific goals. Goals are often difficult to discern, either being unstated, or stated in terms so broad or ambiguous that it is difficult to attach any specific meaning to them. Leaders may enunciate goals, but show little interest in whether they have been 
accomplished (Feldman \& March, 1981). Goal statements seem to interact with practice: they may be derived from practice (Spicker, 2006), or generated in response to a procedural requirement (Chapman, 1993).

So, the explanatory power of the official model is also doubted in the West. There have been different sorts of responses to this. One is a reform agenda: to the extent that practice deviates from the model, it should be made to conform. All activities should state clear objectives, and should be evaluated to confirm that these have been achieved. The government must be seen to govern. Another response has been to see the disjunction between model and experience as evidence of a historical shift: once, the model had been a good description of practice, but circumstances have changed, governing is now more complex, and practice has had to meet the new circumstances. The fullest exposition of this perspective is the argument by Rhodes (1997) that government by authoritative direction has been replaced (or is giving way to) governance by negotiation among self-organising networks, though Rhodes later moved away from this assertion (Bevir \& Rhodes, 2010), and there have been few attempts to produce evidence of the time when practice did resemble that authoritative, instrumental model. A third possibility recognises the place of interpretation in the process of governing: that it calls for people to 'make sense' of the world and their place in it. This recognises that participants may 'make sense' in more than one way, and will need to reach an accommodation with other participants with whom they will be continuing to interact in the managing of this concern. The instrumental assumption that behaviour is governed by perceptions of outcome is challenged by the suggestion that people choose behaviour that is 'appropriate' in the context in which they find themselves (March and Olsen 1989). All three of these responses have been in play in both practice and scholarship.

What we see here is that while these models of governing can be seen as analytic categories, to be finely honed in the seminar room, they are better viewed as constructs in use, mobilised in the accomplishment of governing. Passing laws, appointing high officials, or signing international agreements are part of the performance of 'the state', demonstrating its coherence and authority: the state as actor. But participants know that behind these public performances is a great deal of structured interaction, often painful, aimed at minimising overt resistance to these outcomes (see, e.g., Degeling, Baume \& Jones, 1993). Consequently, accounts of governing have to be appropriate to the context in which they are used. There is a public presentation that sees governing as governments, acting on accurate diagnoses of problems, prescribing clear remedies ('policy'), which will lead to a beneficial outcome. But there is a counter-account, to which the insiders are more attentive, which focuses on the process - the appropriateness of the problematisations, participants, linkage, commitments, and resources - as much as the outcome, and is concerned with the maintenance of the collective, interactive and continuing managing of the problematic aspects of social life.

This means that participants are likely to mobilise different discourses in different contexts, and to be aware of the significance of acting in this way. As one policy worker told a researcher:

this model would not be of great use. ...These words are so neutral. It's not about consultation. It's really about stakeholder engagement (Howard, 2005, p. 10).

This distinction between 'insider' and 'outsider' discourses about governing is well-recognised in the empirical literature, for example, 'front-stage' and 'back-stage' (Goffman, 1959), 'normative rules' and 'pragmatic rules' (Bailey, 1969), and 'sacred' and 'profane' discourses (Degeling \& Colebatch, 1984), though its significance for systematic modelling of governing is less well understood. But while there appear to be two quite different perspectives, in many ways, they are two sides of the same coin, reflecting structural tensions in the governing process: between process and outcome, between central authority and context, between informal ways of working and formal ways of enacting outcomes, and between formal ('sacred') discourses and informal ('profane') activity. Participants learn that accounts need to be appropriate to context, and to match the discourse to the situation. For political leaders, 'authority' will always be a central concern, so the government being seen to have acted appropriately will be regarded as policy success. Central officials are likely to be more concerned with securing acceptance of the policy among the relevant participants (coherence); researchers in that policy field may be more interested in the impact the policy has had on the identified problem (problematisation). All the participants (and all the observers) have a particular and partial view of the action.

\section{THE IMPLICATIONS FOR THE ANALYSIS OF POLICY IN CEE}

The first point to note here is that systematic presentations of modes of governing ('systems') are logical constructions, and not empirical descriptions. So, while it is important to note (and as far as possible, to explain) the differences between observable 
practice and the model in particular cases, this is not an evidence of a 'failure' or 'deficiency' of practice, any more than it shows the 'inaccuracy' or 'failure' of the model; it simply shows that they are different sorts of representation. So, the question, when new institutions and practices are introduced into CEE, is not 'are they being correctly used?', but 'how are they being used, and in what way does their introduction change practice?'

Linked to this is Rose and Miller's point that

Government is a congenitally failing operation ... We do not live in a governed world so much as in a world traversed by the 'will to govern', fuelled by the constant registration of 'failure', the discrepancy between ambition and outcome, and the constant injunction to do better next time (Rose \& Miller, 1992, pp. 190-191)

- $\quad$ and they give an example of the welfare reform in UK:

... welfare was not a coherent mechanism that would enable the unfolding of a central plan. The networks were assembled from diverse and often antagonistic components ... This was no 'state apparatus', but a composition of fragile and mobile relationships and dependencies making diverse attempts to link the aspirations of authorities with the lives of individuals (ibid. p. 193).

This does not suggest that the world has becomes too complex for the state, but that attempts to impose systematic state governing encounter the diversity of human life. This fuels the interest in interpretive approaches, which asks how participants in the process of governing perceive the task - what is to be governed and why, what is known, who should be involved, what is an appropriate response, and how can the governing be judged? In this perspective, governing is less the pursuit of specific goals, and more a matter of appropriate process in the collective managing of the problematic - 'making sense together' (Hoppe, 1999); goals are significant, but as part of the process.

\section{ITEMS FOR THE AGENDA}

The editors have invited me to conclude with some personal viewpoints and reflections, and I thought I might review some of the more significant questions that might be appropriately covered in the journal. This is, of course, a very personal list and should not be taken as an implicit rejection of topics not mentioned.

Since the term 'policy' originated in the Anglosphere, there is little agreement on the precise meaning of the term; though it is distinguished from both 'politics' and 'administration', it is worth asking what is it being used to denote in the CEE, and what is it being distinguished from. A number of translations of policy texts into CEE languages have not translated 'policy', but simply used the English word. It would be interesting to track how the meaning is explained in the language of the translation. (See Hale 1988 on the emergence of 'public policy' in degree programs in the US.)

Similarly, 'policy analysis' is a term that has no inherent meaning, even in its American birthplace, where it emerged from RAND as 'systems analysis'. It is tempting to think it became 'policy analysis' in response to Lasswell's call (1951) for a science of policy, but in any case, Radin (2000) found that those employed as 'policy analysts' were engaged in a wide variety of forms of work, not necessarily related to the systematic comparison of options taught in North American graduate courses in 'policy analysis', and the term now seems on the verge of being supplanted by 'policy design' (Howlett, 2014). It would be valuable to track how the term was introduced, and what sort of activity it has been used to describe.

Particular attention should be given to the way these terms are part of a transnational discourse of governing, emerging from the OECD, the EU, the WTO, the UN family, or the wide array of donor organisations. It would be important to flag the cultural assumptions that are implicit in these introduced terms. For instance, does the idea of 'self-organising networks', or community organisation more generally, assume a relatively high level of interpersonal trust, which may not be found in former socialist societies recovering from systemic disruption (see, e.g., Grdesic \& Koska, 2008, 2009)? How do existing attitudes, skills and practices relate to the assumptions in the introduced model?

The question about policy (and policy analysis) would be not 'has this concept been successfully introduced into CEE?', but 'in what way has this concept been introduced? What is it being used to denote? What organisational positions, practices and outcomes does it validate? And how does it relate to the previous practice? Does it, for instance, impel the codification of 'normal practice' - and in so doing, constrain the autonomy of field staff? 'In other words, 'what part does it play in the practices of governing?' 
In this connection, it may now be possible to attempt some systematic mapping of governing practice under the ancien regime (i.e., before 1989). What factors made situations 'attention-worthy'? How were commitments of resources secured, or extended, or evaded? It may be possible to secure the cooperation of the participants to produce some micro-level historical studies of governing, which can then be compared to how such matters are governed under the new order.

Finally, it would be appropriate to be attentive to the link between theorising and practice, and to theorising as part of practice - that is, the way that participants draw on models as part of practice. Boxelaar et al. (2006) describe a case where agricultural extension staff had worked with farmers to develop an agreed harvesting practice that would reduce the risk of fire. They reported this as an example of collective norm-setting by farmers, but their managers insisted that this be re-written to describe it as a case of the department delivering 'services' to its 'customers' - which would better validate its activities in the eyes of the minister and Treasury than presenting it as empowering a group of farmers. In this way, managers draw on a more favourable conceptualisation to represent (re-present) their activities in a more favourable light. As Kurt Lewin is reputed to have said 'There is nothing more practical than a good theory'.

\section{REFERENCES}

Bailey, F.G. (1969). Stratagems and Spoils. Oxford: Basil Blackwell.

Bevir, M., \& Rhodes, R.A.W. (2010). The State as Cultural Practice. Oxford, UK: Oxford University Press.

Boxelaar, L., Paine, M., \& Beilin, R. (2006). Community engagement and public administration: Of silos, overlays and technologies of government. Australian Journal of Public Administration, 65(1), 113-126.

Buduru, B., \& Pal, L.A. (2010). The globalized state: Measuring and monitoring governance. European Journal of Cultural Studies, 13(4), 511-530.

Chapman, S. (1993). Unravelling gossamer with boxing gloves: Problems in explaining the decline in smoking. British Medical Journal, 307, 429432.

Christensen, T., \& Laegreid, P. (2002). New Public Management: The Transformation of Ideas and Practice. Farnham UK: Ashgate.

Christensen, T., \& Laegreid, P. (2007). Transcending New Public Management. Farnham UK: Ashgate.

Colebatch, H.K. (2005). Policy analysis, policy practice and political science. Australian Journal of Public Administration, 64(3), 14-23.

Colebatch, H.K. (2002). Government and governmentality: using multiple approaches to the analysis of government', Australian Journal of Political Science 3 (3), 417

Dan, S., \& Pollitt, C. (2015). NPM Can Work: An optimistic review of the impact of New Public Management reforms in central and eastern Europe. Public Management Review, 17(9), 1305-1332.

Degeling, P., \& Colebatch, H.K. (1984). Structure and action as constructs in the practice of public administration. Australian Journal of Public Administration, 43(4), 320-331.
Degeling, P., Baume, P., \& Jones, K. (1993). Staqing an official inquiry for policy change: The case of the Drug Evaluation Review in Australia. Policy and Politics, 21(4), 259-274.

Drechsler, W. 2009. The rise and demise of the New Public Management: Lessons and opportunities for South East Europe, International Public Administration Review, 7( 3), 7-27.

Feldman, M.S., \& March, J.G. (1981). Information in organisations as signal and symbol. Administrative Science Quarterly, 26(2), 171-186.

Fukuyama, F. (1989). The end of history? The National Interest, Summer.

Goetz, K.H. (2001). Making sense of post-communist central administration: Modernization, Europeanization or Latinization? Journal of European Public Policy, 8(6), 1032-1051.

Goetz, K.H., \& Wollman, H. (2001). Governmentalizing central executives in post-communist Europe: A four-country comparison. Journal of European Public Policy, 8(6), 864-887. .

Goffman, E. (1959). The Presentation of Self in Everyday Life. New York: Doubleday Anchor.

Grdesic, M., \& Koska, V. (2008). Problem slabih drzava i slabih drustava $\mathrm{u}$ istocnoj Europi [The Weak State-Weak Society Problem of Eastern Europe], Anali hrvatskog politoloskog drustva [Annals of the Croatian Political Science Association]. 5, 241-262.

Grdesic, M., \& Koska, V. (2009). Governance in the Weak StateWeak Society Settings of Eastern Europe. Paper presented at IPSA Conference, Santiago, Chile.

Heretier, A. (2004). New Modes of Governance in Europe: Increasing Political Capacity and Policy Effectiveness. In Borzel, T.A. and Cichowski, R.A. (Eds.), The State of the European Union, 6: Law, Politics and Society. Oxford UK: Oxford Scholarship Online. 
Hale, D. (1988). Just what is a policy, anyway? And who's supposed to make it? Administration and Society, 19(4), 423-452.

Hood, C., \& Peters, G. (2004). The middle aging of New Public Management: Into the age of paradox? Journal of Public Administration Research and Theory, 14(3), 267-282.

Hoppe, R. (1999). Policy analysis, science and politics: From 'speaking truth to power' to 'making sense together'. Science and Public Policy, 26(3), 201-210.

Howard, C. (2005). The policy cycle: A model of post-Machiavellian policy-making? Australian Journal of Public Administration, 64(3), 3-13.

Howlett, M. (2014). From the 'old' to the 'new' policy design: Design thinking beyond markets and collaborative governance. Policy Sciences, 47(3), 187-207.

Kenedi, J. (1982). Do It Yourself: Hungary's Hidden Economy. London: Pluto Press.

Lasswell, H.D. (1951). The Policy Orientation. In D. Lerner and H.D. Lasswell (Eds.), The Policy Sciences. Stanford, CA: Stanford University Press.

Mađarević, E. (2015). The EU's 'Transformative' Power Reassessed - The Case of the Croatian Accession Negotiations. In D. Lajh and Z. Petak (Eds.). EU Public Policies Seen from a National Perspective: Slovenia and Croatia in the European Union. Ljubljana: Faculty of Social Sciences.

March, J.G., \& Olsen, J.P. (1989). Rediscovering Institutions. New York: Free Press.

Meyer-Sahling, J.H. (2009). 'Sustainability of Civil Service Reforms in Central and Eastern Europe Five Years After EU Accession'. Sigma Papers, No. 44, OECD Publishing.

Judt, T. (2006). Postwar. London: Penguin.
Nunberg, B. (1999). The State After Communism: Administrative Transitions in Central and Eastern Europe. Washington D.C.: The World Bank.

Nunberg, B. (2000). Ready for Europe: Public Administration Reform and European Union Accession in Central and Eastern Europe. Washington D.C.: The World Bank.

Pollitt, C., \& Dan, S. (2011). The Impacts of the New Public Management in Europe: A Meta-Analysis. Cocops Work Package 1 - Deliverable 1.1 (www, cocops.eu).

Pollitt, C. (2007). Convergence or divergence: What has been happening? In C. Pollitt, S. Van Thiel and V. Homburg (Eds.). New Public Management in Europe: Adaptation and Alternatives. Basingstoke, UK: Palgrave/ Macmillan.

Potůček, M., Hulík, V., Tesárková, K.H., \& Stejskal, L. (2016). Policy Analysis in the Czech Republic and the Influence of Supranational Organisations. In A. Veselý, M. Nekola and E.M. Hejzlarová (Eds.). Policy Analysis in the Czech Republic. Bristol UK: Policy Press.

Radin, B. (2000). Beyond Machiavelli: Policy Analysis Comes of Age. Washington, D.C.: Georgetown University Press.

Rhodes, R.A.W. (1997). Understanding Governance. Buckingham, UK: Open University Press.

Rose, N., \& Miller, P. (1992). Political power beyond the state: Problematics of government. British Journal of Sociology, 43(2), 172-205. Spicker, P. (2006). Policy Analysis for Practice. Bristol UK: Policy Press. Weick, K.E. (1979). The Social Psychology of Organizing. 2nd ed. Boston MA: Addison-Wesley. 